\title{
Front Matter: Volume 6714
}

, "Front Matter: Volume 6714," Proc. SPIE 6714, Adaptive Coded Aperture Imaging and Non-Imaging Sensors, 671401 (30 October 2007); doi:

10.1117/12.777111

SPIE Event: Optical Engineering + Applications, 2007, San Diego, California, United SPIE. States 


\section{PROCEEDINGS OF SPIE}

\section{Adaptive Coded Aperture Imaging and Non-Imaging Sensors}

David P. Casasent

Timothy Clark

Editors

29-30 August 2007

San Diego, California, USA

Sponsored and Published by

SPIE

Volume 6714 
The papers included in this volume were part of the technical conference cited on the cover and title page. Papers were selected and subject to review by the editors and conference program committee. Some conference presentations may not be available for publication. The papers published in these proceedings reflect the work and thoughts of the authors and are published herein as submitted. The publisher is not responsible for the validity of the information or for any outcomes resulting from reliance thereon.

Please use the following format to cite material from this book:

Author(s), "Title of Paper," in Adaptive Coded Aperture Imaging and Non-Imaging Sensors, edited by David P. Casasent, Timothy Clark, Proceedings of SPIE Vol. 6714 (SPIE, Bellingham, WA, 2007) Article CID Number.

ISSN 0277-786X

ISBN 9780819468628

Published by

SPIE

P.O. Box 10, Bellingham, Washington $98227-0010$ USA

Telephone +1 3606763290 (Pacific Time) · Fax +1 3606471445

SPIE.org

Copyright (c) 2007, Society of Photo-Optical Instrumentation Engineers

Copying of material in this book for internal or personal use, or for the internal or personal use of specific clients, beyond the fair use provisions granted by the U.S. Copyright Law is authorized by SPIE subject to payment of copying fees. The Transactional Reporting Service base fee for this volume is $\$ 18.00$ per article (or portion thereof), which should be paid directly to the Copyright Clearance Center (CCC), 222 Rosewood Drive, Danvers, MA 01923. Payment may also be made electronically through CCC Online at copyright.com. Other copying for republication, resale, advertising or promotion, or any form of systematic or multiple reproduction of any material in this book is prohibited except with permission in writing from the publisher. The CCC fee code is $0277-786 \mathrm{X} / 07 / \$ 18.00$.

Printed in the United States of America.

Publication of record for individual papers is online in the SPIE Digital Library.

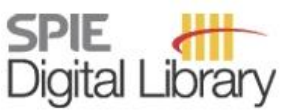

SPIEDigitalLibrary.org

Paper Numbering: Proceedings of SPIE follow an e-First publication model, with papers published first online and then in print and on CD-ROM. Papers are published as they are submitted and meet publication criteria. A unique, consistent, permanent citation identifier (CID) number is assigned to each article at the time of the first publication. Utilization of CIDs allows articles to be fully citable as soon they are published online, and connects the same identifier to all online, print, and electronic versions of the publication. SPIE uses a six-digit CID article numbering system in which:

- The first four digits correspond to the SPIE volume number.

- The last two digits indicate publication order within the volume using a Base 36 numbering system employing both numerals and letters. These two-number sets start with $00,01,02,03,04,05$, 06, 07, 08, 09, OA, OB ... 0Z, followed by 10-1Z, 20-2Z, etc.

The CID number appears on each page of the manuscript. The complete citation is used on the first page, and an abbreviated version on subsequent pages. Numbers in the index correspond to the last two digits of the six-digit CID number. 


\title{
Contents
}

\author{
$\checkmark \quad$ Conference Committee
}

\section{SESSION 1 IMAGING AND NON-IMAGING SENSORS NEEDS}

671402 Challenges in the evolution of advanced imaging systems (Keynote Paper) [6714-01]

K. Lewis, Sciovis Ltd. (United Kingdom) and QinetiQ (United Kingdom)

671403 DARPA interest in diffractive sensors (Invited Paper) [6714-02]

T. Clark, Defense Advanced Research Projects Agency (USA); E. Jaska, Independent

Consultant (USA)

\section{SESSION 2 IMAGING AND NON-IMAGING DIFFRACTIVE SYSTEM CONCEPTS}

671405 Coded apertures: past, present, and future application and design [6714-04]

S. R. Gottesman, Northrop Grumman Corp. (USA)

671406 Agile, detecting and discriminating, infrared electro-optical system (ADDIOS) application to coded aperture imaging and non-imaging sensor systems [6714-05]

M. Gutin, Applied Science Innovations, Inc. (USA); S. Rogers, Air Force Research Lab. (USA);

O. Gutin, X.-M. Wang, Applied Science Innovations, Inc. (USA); D. Warner, J. Gueits, Air

Force Research Lab. (USA)

671407 Large-scale optical lensless imaging with geometric fiber constructs [6714-06]

A. F. Abouraddy, Y. Fink, Massachusetts Institute of Technology (USA)

671408 An investigation of the potential for the use of a high resolution adaptive coded aperture system in the mid-wave infrared [6714-07]

C. Slinger, QinetiQ (United Kingdom); M. Eismann, Air Force Research Lab. (USA);

N. Gordon, K. Lewis, G. McDonald, M. McNie, D. Payne, K. Ridley, M. Strens, G. De Villiers,

R. Wilson, QinetiQ (United Kingdom)

671409 Beam steering and pointing with counter-rotating grisms [6714-08]

C. B. Chen, Raytheon Co. (USA)

\section{SESSION 3 DIFFRACTIVE IMAGING HARDWARE}

$6714 \mathrm{OB}$ Reconfigurable mask for adaptive coded aperture imaging (ACAI) based on an addressable MOEMS microshutter array [6714-11]

M. E. McNie, D. J. Combes, G. W. Smith, N. Price, K. D. Ridley, K. M. Brunson, K. L. Lewis,

C. W. Slinger, QinetiQ Ltd. (United Kingdom); S. Rogers, Air Force Research Labs. (USA) 
6714 OC Dynamic aperture optical arrays based on polymeric MEMS actuators for large scale coding elements with application in visible to MWIR [6714-12]

S. Goodwin, J. Carlson, RTI International (USA); S. Rogers, Air Force Research Lab. (USA); J. Kim, C. Kim, D. Brady, Duke Univ. (USA); B. R. Stoner, RTI International (USA) and Duke Univ. (USA)

6714 OD IR performance study of an adaptive coded aperture diffractive imaging system employing MEMS eyelid shutter technologies [6714-13]

A. Mahalanobis, C. Reyner, H. Patel, T. Haberfelde, Lockheed Martin Missiles and Fire Control (USA); D. Brady, Duke Univ. (USA); M. Neifeld, Univ. of Arizona (USA);

B. V. K. V. Kumar, Carnegie Mellon Univ. (USA); S. Rogers, Air Force Research Lab. (USA)

6714 OE Eclipse SteerTech liquid lenslet beam steering technology [6714-15]

R. T. Westfall, Eclipse Energy Systems, Inc. (USA); S. Rogers, Air Force Research Lab. (USA);

K. C. Shannon III, Eclipse Energy Systems, Inc. (USA)

\section{SESSION 4 IMAGING AND NON-IMAGING ALGORITHMS}

6714 OF System models for IR diffractive optical systems based on a coherence theoretic framework [6714-16]

N. Subotic, Michigan Tech Research Institute (USA); M. Eismann, Air Force Research Lab. (USA); C. Roussi, Michigan Tech Research Institute (USA); J. Meola, Air Force Research Lab. (USA); B. Koziol, Michigan Tech Research Institute (USA)

$6714 \mathrm{OH}$ Discrete adaptive zone light elements (DAZLE): a new approach to adaptive imaging (Invited Paper) [6714-18]

R. L. Kellogg, Argon ST Inc. (USA); M. J. Escuti, North Carolina State Univ. (USA)

POSTER SESSION

6714 0J Interferometric control of contact line, shape, and aberrations of liquid lenses [6714-14] I. Voitenko, R. Storm, R. Westfall, Eclipse Energy Systems, Inc. (USA); S. Rogers, Air Force Research Lab. (USA)

Author Index

iv 


\title{
Conference Committee
}

\author{
Conference Chairs \\ David P. Casasent, Carnegie Mellon University (USA) \\ Timothy Clark, Defense Advanced Research Projects Agency (USA) \\ Program Committee \\ David J. Brady, Duke University (USA) \\ Michael T. Eismann, Air Force Research Laboratory (USA) \\ Stephen R. Gottesman, Northrop Grumman Corporation (USA) \\ Abhijit Mahalanobis, Lockheed Martin Missiles and Fire Control (USA) \\ Mark A. Neifeld, University of Arizona (USA) \\ Demetri Psaltis, California Institute of Technology (USA) \\ Stanley Rogers, Air Force Research Laboratory (USA) \\ Christopher W. Slinger, QinetiQ (United Kingdom) \\ Nikola S. Subotic, Michigan Tech Research Institute (USA) \\ Rebecca A. Wilson, QinetiQ (United Kingdom) \\ Session Chairs \\ $1 \quad$ Imaging and Non-Imaging Sensors Needs \\ Timothy Clark, Defense Advanced Research Projects Agency (USA) \\ David P. Casasent, Carnegie Mellon University (USA) \\ 2 Imaging and Non-Imaging Diffractive System Concepts \\ Stephen R. Gottesman, Northrop Grumman Corporation (USA) \\ 3 Diffractive Imaging Hardware \\ Stanley Rogers, Air Force Research Laboratory (USA) \\ $4 \quad$ Imaging and Non-Imaging Algorithms \\ Nikola S. Subotic, Michigan Tech Research Institute (USA)
}


Downloaded From: https://www.spiedigitallibrary.org/conference-proceedings-of-spie on 26 Apr 2023

Terms of Use: https://www.spiedigitallibrary.org/terms-of-use 